\title{
Effects of foliar sulfur applications in cotton crop on stomatal conductance under water stress
}

Pamuk bitkisinde yapraktan kükürt uygulamalarının uzun süreli su stresi koşullarında stoma iletkenliğine etkisi

\section{Derya KAZGÖZ CANDEMiR ${ }^{1}$ iD , Berkant ÖDEMiş ${ }^{1 / 2}$}

${ }^{1}$ Hatay Mustafa Kemal University, Faculty of Agriculture, Department of Biosystems Engineering, Antakya-Hatay, Turkey.

MAKALE BILGISI / ARTICLE INFO

Makale tarihçesi / Article history:

DOI: $\underline{10.37908 / m k u t b d .806526}$

Geliş tarihi /Received:06.10.2020

Kabul tarihi/Accepted:17.12.2020

\section{Keywords:}

Cotton (Gossypium hirsutum L.), deficit irrigation, different growth stages, foliar sulfur application, stomatal conductance.

Corresponding author: Derya KAZGÖZ
CANDEMiR
$\bowtie:$ dryaa.kzgz@gmail.com

\section{ÖZET / ABSTRACT}

Atıf / Citation: Kazgöz Candemir D, Ödemiş B, (2021) Pamuk Bitkisinde Yapraktan Kükürt Uygulamalarının Uzun Süreli Su Stresi Koşullarında Stoma İletkenliğine Etkisi. MKU. Tar. Bil. Derg. 26(1) : 171-182. DOI: 10.37908/mkutbd.806526

\section{INTRODUCTION}

Agricultural areas suffer from various stresses including climate change, environmental pollution, and land use/cover change. Globally, the cultivated areas are adversely affected by drought stress (26\%), overfertilization (20\%), frost conditions (15\%), and other stress factors (29\%), while the completely stress-free croplands make up only 10\% (Blum, 1986; González et al., 2008). Amongst the abiotic stresses, water stress has 
been considered as a threat for low crop productivity in many regions of the world (Turner, 1997; Sinclair, 2005; Sezener et al., 2015). Therefore, the use of droughttolerant plants, and the enhancement of the drought tolerance of the crop production play a vital role in food and water securities. Inefficient and ineffective irrigation practices are the primary driver of sustainable agriculture (Kazgoz Candemir and Odemis, 2018), in particular, in the (semi-)arid climate belts (Ozyurt and Akca, 2017).

The water stress impact depends on the stress severity and duration, and the plant development stage and genotype (Loka and Oosterhuis, 2012). Water stress during the flowering and boll stages of the crop development was reported to cause a significant yield loss (Krieg, 1997; Orgaz et al., 1992; Loka, 2012; Loka ans Oosterhuis, 2012). As with other crops, cotton responds to water stress with various physiological strategies among which decreased stomatal conductance, increased leaf temperature (Jones, 1999), weakened photosynthetic capacity (Lawlor and Cornic, 2002), shortened phenological periods (Slafer et al., 2005; Richards, 2006) and reduced leaf area (Walter and Shurr, 2005) are some of the most important ones. Stomatal conductance/resistance is one of the most important mechanisms of the plant physiology since it allows for the gas exchange between the stoma and the atmosphere (Kerepesi and Galiba, 2000; Mansfield and Davies, 1981). Various studies about potassium (Andersen et al., 1992), phosphorus (Sawwan et al., 2000), boron (Odemis and Delice, 2018), and sulfur

(Odemis et al., 2017; Kazgoz Candemir and Odemis, 2018) showed that they reduced the plant water stress. The most typical signals of the sulfur deficiency included the paling of young leaves as a result of reduced protein and chlorophyll synthesis, the declined root hydraulic permeability, the decreased stoma openings, and the diminished leaf areas (Dietz, 1989; Marschner, 1995; Jie et al., 2008).

The objective of this study was to determine how foliar sulfur applications affect the stomatal conductance of cotton when drip-irrigated and subjected to water stress during the different development stages.

\section{MATERIALS AND METHODS}

The study was performed in the agricultural experimental station of the firm ProGen Seed Company in Hatay in the eastern Mediterranean region of Turkey ( $36^{\circ} 17^{\prime} 26^{\prime \prime} \mathrm{N}$ latitude and $36^{\circ} 11^{\prime} 43^{\prime \prime}$ E longitude). The experimental design was based on the randomized complete block with three replications in full irrigation in 2015 and 2016. The average temperatures recorded during the growing seasons (May, June, July, August, September, and October) in 2015 and 2016 were $26.9^{\circ} \mathrm{C}$ and $25.9^{\circ} \mathrm{C}$, with the total rainfall of $21 \mathrm{~mm}$ and $149 \mathrm{~mm}$, respectively. The soil is composed of silt, clay, and loam with no issue of saline-sodium content or drainage. In the soil samples taken to a depth of $30 \mathrm{~cm}$, no sulfur was detected based on the turbidimetric barium method (Fox et al., 1964). Their physical properties are given in Table 1.

Table 1. Soil properties of the experimental area

\begin{tabular}{|c|c|c|c|c|c|c|}
\hline \multirow[b]{2}{*}{ Depth $(\mathrm{cm})$} & \multicolumn{3}{|c|}{ Texture class } & \multirow[b]{2}{*}{$\mathrm{FC}(\%, \mathrm{Pw})$} & \multirow{2}{*}{ WP $(\%, P w)$} & \multirow{2}{*}{$\mathrm{BD}\left(\mathrm{g} \mathrm{cm}^{-3}\right)$} \\
\hline & Sand (\%) & Silt (\%) & Clay (\%) & & & \\
\hline $0-30$ & 59.5 & 15.3 & 25.2 & 21.3 & 13.4 & 1.66 \\
\hline $30-60$ & 57.5 & 19.3 & 23.2 & 24.1 & 14.2 & 1.68 \\
\hline $60-90$ & 53.5 & 17.3 & 29.2 & 25.0 & 14.5 & 1.54 \\
\hline $90-120$ & 61.5 & 15.3 & 23.2 & 25.2 & 14.7 & 1.49 \\
\hline
\end{tabular}

FC: Field capacity, WP: Wilting point, BD: ;Bulk density

Drip irrigation system was used in the treatments. In the experiment, laterals were used with a dripper gap of 40 $\mathrm{cm}$ and placed one in every other row. Irrigation was performed once a week by bringing the existing level of moisture (based on TTT as the reference) to the field capacity. Irrigation water quality was as $\mathrm{C}_{3} \mathrm{~S}_{1}$ (ECw: 1397 $\left(\mu\right.$ mhos $\left.\mathrm{cm}^{-1}\right)$. Carisma cotton cultivar used in the treatment was planted and harvested from May 18 to October 14 in 2015 and from June 3 to October 14 in 2016. In its different development periods, cotton was either irrigated at the field capacity $(\mathrm{T})$ or received no irrigation (O) (Table 2). The development periods included vegetative growth (VG), flowering and boll development (FB) and boll opening (BO) (Doorenbos and Kassam, 1979). For each growth stage, there were six rows of cottons, while rows were $15 \mathrm{~m}$ in length for each replication. There was no gap between the replications. Space between plant rows was $70 \mathrm{~cm}$ and space between plants was $15 \mathrm{~cm}$. There were approximately 100 plants on each row. 
Table 2. Water stress treatments applied in different cotton crop developmental stages

\begin{tabular}{lcccc}
\hline Treatments & $\begin{array}{c}\text { Emergence } \\
\text { water* }\end{array}$ & $\begin{array}{c}\text { Vegetative Growth } \\
\text { Period (VG) }\end{array}$ & $\begin{array}{c}\text { Flowering and Boll Development } \\
\text { Period (FB) }\end{array}$ & $\begin{array}{c}\text { Boll Opening Period } \\
\text { (BO) }\end{array}$ \\
\hline OOO & + & - & - & - \\
OTO & + & - & + & - \\
TOO & + & + & - & - \\
OTT & + & - & + & + \\
TOT & + & + & - & + \\
TTT & + & + & + & + \\
\hline
\end{tabular}

$(+):$ Irrigation, (-): Non-irrigation

(T): Irrigation treatments irrigated at field capacity level, (O): Non-Irrigation treatments

*: In the first year, $70 \mathrm{~mm}$ water was given for equal emergence, while there was no need to irrigate in the second year due to precipitation

The soil moisture change was determined through the gravimetric method for a soil depth of $30 \mathrm{~cm}$ at the effective root depth of $90 \mathrm{~cm}$. The first irrigation was started after $50 \%$ of the available water capacity was consumed. Evapotranspiration rate of the samples was calculated through the 'Soil-Water Budget' method thus: $E t=I+R-D p-R f \pm \Delta S$

where Et: Evapotranspiration (mm); l: Amount of supplied irrigation water $(\mathrm{mm}) ; R$ : rainfall $(\mathrm{mm}) ; D p$ : deep percolation $(\mathrm{mm})$ (measured based on the samples taken nearly 24 hours after the irrigation of fully irrigated samples at $120 \mathrm{~cm}$ depth); $R f$ : the surface runoff $(\mathrm{mm})$; and $\triangle S$ : the soil moisture content change values $(\mathrm{mm} 90$ $\mathrm{cm}^{-1}$ ) (James, 1988).
The fertilizer treatments were performed in the same way for all the plots at the same dose prevalently used in the region: $20 \mathrm{~kg} \mathrm{da}^{-1} 18-46-0$ (DAP) fertilizer before and after sowing. $4 \mathrm{~kg} \mathrm{da}^{-1}$ pure $\mathrm{N}$ fertigation in each of the four irrigations were applied based on the four quarters rule, as was stated by Burt et al. (1995) (So). For all the treatments, pure elemental sulfur was applied from the leaves as $150 \mathrm{~mL} \mathrm{da}^{-1}\left(\mathrm{~S}_{1}\right), 250 \mathrm{ml} \mathrm{da}^{-1}\left(\mathrm{~S}_{2}\right), 350$ $\mathrm{ml} \mathrm{da}^{-1}\left(\mathrm{~S}_{3}\right)$ (Table 3). Sulfur applications were made one time in the middle of each of the development periods, except for the emergence period, and between two irrigations at the early hours of the morning (6:00-6:30) where the wind would not negatively affect the $S$ distribution.

Table 3. Application dates and Sulfur doses applied to treatments

\begin{tabular}{llll}
\hline Sulfur doses & First Application & Second application & Third application \\
\hline$S_{0}$ & No application & & \\
$S_{1}$ & $150 \mathrm{ml} \mathrm{da}^{-1}$ & $150 \mathrm{ml} \mathrm{da}^{-1}$ & $150 \mathrm{ml} \mathrm{da}^{-1}$ \\
$\mathrm{~S}_{2}$ & $250 \mathrm{ml} \mathrm{da}^{-1}$ & $250 \mathrm{ml} \mathrm{da}^{-1}$ & $250 \mathrm{ml} \mathrm{da}^{-1}$ \\
$\mathrm{~S}_{3}$ & $350 \mathrm{ml} \mathrm{da}^{-1}$ & $350 \mathrm{ml} \mathrm{da}^{-1}$ & $350 \mathrm{ml} \mathrm{da}^{-1}$ \\
\hline
\end{tabular}

\section{Stomatal conductance}

Stomatal conductance measurements were made 1 day before irrigation, between 11:00-14:00 under the clear sky and on two leaves of two plants marked for the replications of each subject. The device SC-1 (LPS0881) leaf porometer was used for stomatal conductance measurements. Before each measurement in the field, device calibration checks were carried out with the standard calibration papers, and having awaited the stabile weather conditions.

\section{Yield $\left(\mathrm{kg} \mathrm{da}^{-1}\right)$ and statistical analysis}

Each experiment plot consisted of six rows. Two rows from the edges, and $0.50 \mathrm{~m}$ from the beginning and end of each row were left out due to the edge effect. The remaining area of $13.05 \mathrm{~m}^{2}$ was harvested and total yield was calculated in $\mathrm{kg} \mathrm{da}^{-1}$. The statistical analysis was performed processing the data using Duncan Test in SPSS 18 software package (Bek and Efe, 1988). 


\section{RESULT AND DISCUSSION}

\section{Irrigation water (mm)}

The highest irrigation amount was received by the fully irrigated (TTT) treatment in each of its developmental period (Table 4). In both years, the first irrigations were made when approximately $50 \%$ of the available capacity was used up, while the rest was usually applied once a week in the range of $50-60 \%$ of available capacity, considering the soil water content with TTT. Irrigation was started on July 10 in the first year and July 14 in the second year and ended on August 27 in both years. The amount of rainfall was $21 \mathrm{~mm}$ from the date of planting to harvest in the first year and $149 \mathrm{~mm}$ in the second year by the time of harvest. The number of irrigations was 10 and 7 in the first and second years, respectively. The reason for the difference related to the rainfall received during the two irrigation seasons. The average water amount used in each irrigation was $127.5 \mathrm{~mm}$ $(115-140 \mathrm{~mm})$ and $138 \mathrm{~mm}(107-169 \mathrm{~mm})$ in the first and second years, respectively. With the same cotton variety in the same region during the same years as this study, the irrigation water amount for each full irrigation was on average not less than $110 \mathrm{~mm}$ given the soil water deficit according to Odemis et al., (2017).

Table 4. Irrigation water, evapotranspiration (Et) and yield according to the treatments

\begin{tabular}{|c|c|c|c|c|}
\hline \multirow{2}{*}{ Treatments } & \multicolumn{2}{|c|}{ Irrigation Water (mm) } & \multicolumn{2}{|c|}{ Evapotranspiration (mm) } \\
\hline & 2015 & 2016 & 2015 & 2016 \\
\hline 000 & $91^{*}$ & $149 * *$ & 304 & 256 \\
\hline TTT & 1136 & 1078 & 1012 & 1070 \\
\hline TOO & 350 & 570 & 380 & 639 \\
\hline OTT & 877 & 657 & 770 & 636 \\
\hline Ото & 478 & 407 & 583 & 425 \\
\hline ТОТ & 749 & 820 & 685 & 787 \\
\hline
\end{tabular}

*: Precipitation+emergence water

**: Precipitation

Precipitation and emergence water are included in all treatments

In both years, the highest and lowest ET values occurred with TTT and OOO, respectively (Table 4). The ET values varied between 304 and $1012 \mathrm{~mm}$ in the first year and between 256 and $1070 \mathrm{~mm}$ in the second year. With TT, TOO, ОТT, ОTO, and TOT, the ET values decreased by 62 , 24,42 , and $32 \%$ in 2015, and 40, 41, 60, and 26\% in 2016. The difference may be attributed to the different growing season length, temperature and rainfall. The ET value was in the range of 299 to $1096 \mathrm{~mm}$ in 2015 and 247 to $995 \mathrm{~mm}$ in 2016 according to the study by Odemis et al. (2017) about the effects of boron on cotton flowering under the water levels $(33 \%, 66 \%$ and $100 \%$ of the available capacity) in different doses $(0.75 \mathrm{ppm}, 300$ ppm, and $750 \mathrm{ppm}$ ). The ET value varied between 274 and $1045 \mathrm{~mm}$ according to the study by Odemis and Delice (2018) and between 921 and $500 \mathrm{~mm}$ in Kahramanmaras (Keten et al., 2019).

\section{Relation of stomatal conductance and the irrigation water}

Higher stomatal conductance means open stomata with high transpiration rate. In both years, stomatal conductance was affected by the amount of irrigation water applied during the development period (DP) and by the interaction of the sulfur dose and irrigation water amount in these periods $\left(D P^{*} S D\right)(p<0.001)$, whereas sulfur doses (SD) did not affect stomatal conductance (Table 5). 
Table 5. Analysis of variance table for stomatal conductance

\begin{tabular}{llllll}
\hline Year & Source of variation & $\mathrm{df}$ & $\mathrm{SS}$ & $\mathrm{MS}$ & $\mathrm{F}$ \\
\hline \multirow{4}{*}{2015} & DP & 5 & 14432512.45 & 2886502.49 & $190.23^{* * *}$ \\
& SD & 3 & 124527.08 & 41509.03 & $2.74 \mathrm{~ns}$ \\
& DP*SD & 15 & 728941.92 & 48596.13 & $3.20^{* * *}$ \\
\hline \multirow{5}{*}{2016} & 252 & 3823715.72 & 15173.48 & \\
\hline & Error & 5 & 1340429.68 & 268085.94 & $101.31^{* * *}$ \\
& SD & 3 & 7448.38 & 2482.79 & $0.94 \mathrm{~ns}$ \\
& DP*SD & 15 & 101564.41 & 6770.96 & $2.56^{* * *}$ \\
\hline \multirow{5}{*}{$2015-2016$} & 240 & 635117.70 & 2646.32 & \\
& Error & 5 & 12170143 & 2434029 & $268.58^{* * *}$ \\
& DP & 3 & 70918.88 & 23639.63 & $2.61^{*}$ \\
& SD & 10 & 15958621 & 1595862 & $176.09^{* * *}$ \\
& Year & 15 & 546222.8 & 36414.85 & $4.02^{* * *}$ \\
& DP*SD & 50 & 24585057 & 491701.1 & $54.26^{* * *}$ \\
& SD*Year & 28 & 1120546 & 40019.51 & $4.42^{* * *}$ \\
& DP*SD*Year & 140 & 3277045 & 23407.46 & $2.58^{* * *}$ \\
& Error & 492 & 4458833 & 9062.67 & \\
\hline
\end{tabular}

DP: development period, SD: sulfur doses, df: degree of freedom, SS: Sum of square, MS: Mean Squares, ${ }^{* * *} p<0.001$, ** $p<0.01, * p<0.05$ significant, ns: not significant

Average stomatal conductance varied between 269 and $1067 \mathrm{mmol} \mathrm{m}^{-2} \mathrm{~s}^{-1}$ in the first year and between 205 to $407 \mathrm{mmol} \mathrm{m}^{-2} \mathrm{~s}^{-1}$ in the second year. In the first year, all the subjects significantly differed from one another, while a significant difference between TOO and OTT, and OTO and TOT was detected in the second year. In both years, TTT with the highest stomatal conductance significantly differed from the rest (Table 6). The decreased irrigation water decreased the stomatal conductance. In the first year, the decrease in the irrigation water from 1136 to $91 \mathrm{~mm}$ decreased the stomatal conductance by $69 \%$. In the second year, the decrease from 1078 to $149 \mathrm{~mm}$ decreased the stomatal conductance by $50 \%$. The highest average stomatal conductance was found with TTT in both years. The stomatal conductance fell with TOO, OTT, OTO, and TOT by $73,37,75$, and $43 \%$ in 2015 and $29,28,37$, and $34 \%$ in 2016, respectively (Table 6). The decreased irrigation water prolonged the duration of stress and decreased the stomatal conductance. These results are in agreement with Loka and Oosterhuis (2014); Odemis et al. (2017); Can (2017). Whether the stress was prolonged as with 000 or short-lived as with TOT or OTT determines the yield. The pronounced stress responses of cotton at the different developmental stages also showed how the $S$ dosage applied affected the stomatal conductance. 
Table 6. Stomatal conductance $(\mathrm{Sc})\left(\mathrm{mmol} \mathrm{m}^{-2} \mathrm{~s}^{-1}\right)$ and yield $\left(\mathrm{kg} \mathrm{da}^{-1}\right)$ according to the treatments

\begin{tabular}{|c|c|c|c|c|c|}
\hline \multirow{2}{*}{\multicolumn{2}{|c|}{ Applications }} & \multicolumn{2}{|c|}{2015} & \multicolumn{2}{|c|}{2016} \\
\hline & & Yield & SC & Yield & $\mathrm{SC}$ \\
\hline \multicolumn{2}{|c|}{000} & 252 & 332 & 168 & 205 \\
\hline \multicolumn{2}{|c|}{ TTT } & 533 & 1066 & 564 & 406 \\
\hline \multicolumn{2}{|c|}{ TOO } & 236 & 286 & 272 & 290 \\
\hline \multicolumn{2}{|c|}{ OTT } & 451 & 670 & 337 & 294 \\
\hline \multicolumn{2}{|c|}{ Ото } & 287 & 269 & 322 & 256 \\
\hline \multicolumn{2}{|c|}{ TOT } & 305 & 610 & 356 & 269 \\
\hline \multicolumn{2}{|c|}{ Development Period (DP) } & $* * *$ & $* * *$ & $* * *$ & $* * *$ \\
\hline \multicolumn{2}{|c|}{$S_{0}$} & 316 & 521 & 301 & 405 \\
\hline \multicolumn{2}{|c|}{$\mathrm{S}_{1}$} & 348 & 546 & 352 & 395 \\
\hline \multicolumn{2}{|c|}{$\mathrm{S}_{2}$} & 361 & 554 & 344 & 395 \\
\hline \multicolumn{2}{|c|}{$\mathrm{S}_{3}$} & 352 & 533 & 348 & 392 \\
\hline \multicolumn{2}{|l|}{ Sulfur Dose (SD) } & Ns & ns & $* * *$ & ns \\
\hline \multirow{4}{*}{000} & $\mathrm{~S}_{0}$ & 186 & 297 & 149 & 231 \\
\hline & $S_{1}$ & 237 & 353 & 150 & 191 \\
\hline & $\mathrm{S}_{2}$ & 288 & 351 & 189 & 197 \\
\hline & $\mathrm{S}_{3}$ & 296 & 326 & 183 & 199 \\
\hline \multirow{4}{*}{ TTT } & $\mathrm{S}_{0}$ & 480 & 1127 & 500 & 430 \\
\hline & $S_{1}$ & 547 & 1057 & 581 & 387 \\
\hline & $\mathrm{S}_{2}$ & 560 & 1021 & 586 & 405 \\
\hline & $\mathrm{S}_{3}$ & 544 & 1060 & 587 & 403 \\
\hline \multirow{4}{*}{ TOO } & $\mathrm{S}_{0}$ & 203 & 246 & 258 & 261 \\
\hline & $S_{1}$ & 253 & 363 & 298 & 312 \\
\hline & $\mathrm{S}_{2}$ & 244 & 314 & 277 & 324 \\
\hline & $\mathrm{S}_{3}$ & 244 & 221 & 255 & 263 \\
\hline \multirow{4}{*}{ OTT } & $\mathrm{S}_{0}$ & 459 & 616 & 328 & 287 \\
\hline & $\mathrm{S}_{1}$ & 443 & 641 & 351 & 281 \\
\hline & $\mathrm{S}_{2}$ & 466 & 723 & 333 & 312 \\
\hline & $\mathrm{S}_{3}$ & 437 & 699 & 337 & 296 \\
\hline \multirow{4}{*}{ ото } & $\mathrm{S}_{0}$ & 303 & 227 & 259 & 244 \\
\hline & $S_{1}$ & 280 & 302 & 338 & 253 \\
\hline & $\mathrm{S}_{2}$ & 285 & 283 & 340 & 242 \\
\hline & $\mathrm{S}_{3}$ & 280 & 265 & 350 & 286 \\
\hline \multirow{4}{*}{ TOT } & $\mathrm{S}_{0}$ & 263 & 615 & 314 & 278 \\
\hline & $\mathrm{S}_{1}$ & 326 & 561 & 396 & 273 \\
\hline & $\mathrm{S}_{2}$ & 322 & 634 & 337 & 275 \\
\hline & $\mathrm{S}_{3}$ & 308 & 628 & 378 & 249 \\
\hline DP x SD & & ns & $* * *$ & ns & $* * *$ \\
\hline
\end{tabular}

In the first year, the lowest stomatal conductance was obtained with 000 and ОTO when the subject did not receive any $S$ dosage $\left(S_{0}\right)$. The highest stomatal conductance was obtained with the $S_{1}$ dose, while the stomatal conductance declined with the elevated $S$ dose. With the doses of $S_{1}, S_{2}$, and $S_{3}$, the stomatal 
conductance increased by 19,18 and $10 \%$ for 000 and 33,25 and $17 \%$ for OTO, respectively. As far as TTT, irrigated to the field capacity at all the developmental stages, was concerned, the stomatal conductance increased by 6, 9 and 6\% in 2015 and decreased by 10, 6 and $6 \%$ in 2016 with $S_{1}, S_{2}$, and $S_{3}$, respectively. These results showed that the $S$ application did not increase the maximum stomatal conductance when the soil had sufficient moisture. When the soil water content was sufficient, the foliar $\mathrm{S}$ applications prevented the further opening of stomata. On the contrary, potential gas exchange rate might be reduced due to the prohibitive layer $\mathrm{S}$ formed on the leaf surface. Nevertheless, the $\mathrm{S}$ application increased the stomatal conductance. As for TOO, fully irrigated in the vegetative period, $S_{1}$ and $S_{2}$ increased the stomatal conductance by 48 and $28 \%$ in 2015 and 20 and $24 \%$ in 2016, respectively. It is of great significance that these increases occurred in leaves that had to endure early aging due to stress in the flowering, and boll development and opening periods.

In both years, a significant relation for the amount of irrigation water was found with ET and stomatal conductance $(p<0.01)$. One unit increase in irrigation water and ET increased the stomatal conductance by 0.74 and $1.07 \mathrm{mmol} \mathrm{m}^{-2} \mathrm{~s}^{-1}$ in the first year and 0.19 and $0.21 \mathrm{mmol} \mathrm{m}^{-2} \mathrm{~s}^{-1}$ in the second year (Figure 1).
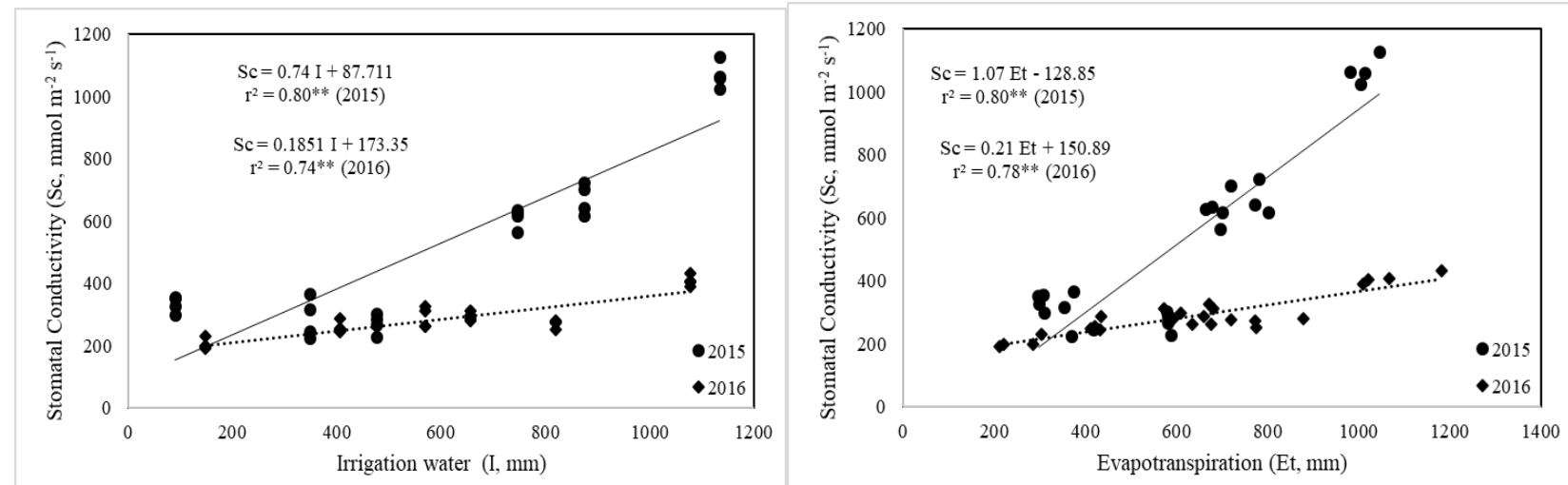

Figure 1. The relationship between irrigation water and evaporatranspiration and stomatal conductance

In the first year, the highest stomatal conductance was observed with TOO at a dose of $150 \mathrm{ml} \mathrm{da}^{-1}$ where the yield was also higher (Table 6). The doses after $150 \mathrm{ml}$ $\mathrm{da}^{-1}$ did not make any difference in the yield and decreased the stomatal conductance, a stress in the plant. A similar effect was observed with OTT in 2015, with the highest yield obtained at $250 \mathrm{ml} \mathrm{da}^{-1}$ and the highest stomatal conductance, both of which dropped with the increased dose. As for ОTO in 2016, the increased $S$ dose increased both stomatal conductance and yield, with the highest ones obtained at $350 \mathrm{ml} \mathrm{da}^{-1}$ for both. Considering each developmental period separately, the duration and intensity of the stress that the plant was exposed during the developmental period are the main driver of the change in the stomatal conductance. The effect of the $S$ application on the increased stomatal conductance varied depending on its dosage and the level of stress.

In both years, a significant relation $(p<0.01)$ was found between stomatal conductance and yield. One unit increase in the stomatal conductance increased the yield by $0.35 \mathrm{~kg} \mathrm{da}^{-1}$ in the first year and $1.69 \mathrm{~kg} \mathrm{da}^{-1}$ in the second year (Figure 2). 


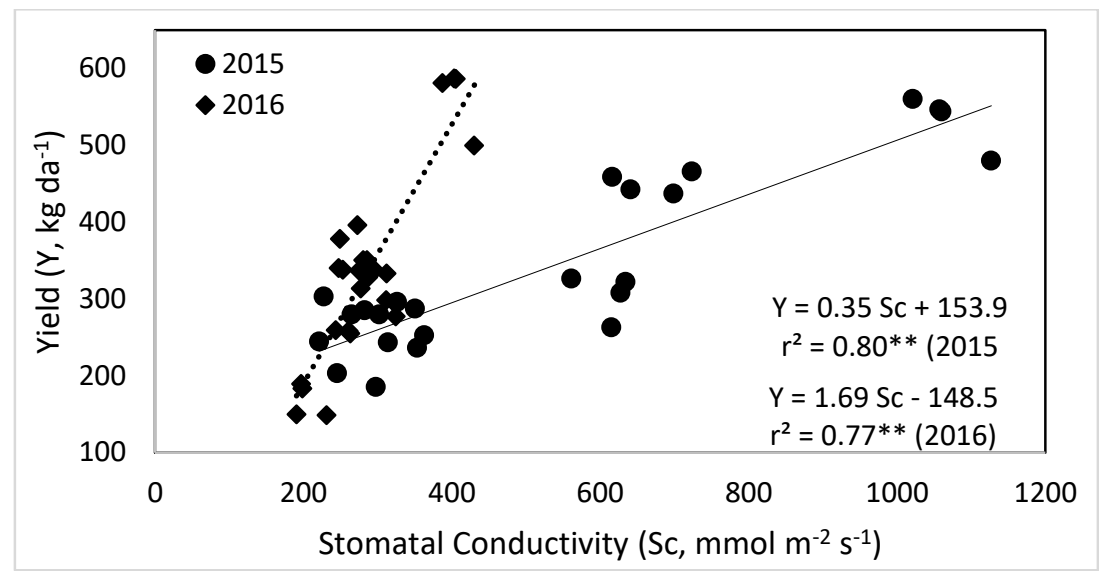

Figure 2. The relationship between stomatal conductance and yield

The length of the non-irrigated duration in the developmental periods (stress duration and severity), and the $\mathrm{S}$ doses are the reason why the stomatal conductance varied temporally (Figure 3-4).

For the first year, with the long-term stress (0OO), the $S_{1}, S_{2}$ and $S_{3}$ doses had a relatively positive effect on the stomatal conductance when compared to the $S_{0}$ dose, with the $\mathrm{S}_{2}$ dose as the biggest contributor (Figure 3). In the second year, the $S$ doses had a negative effect, and thus, decreased the stomatal conductance. Even though the initial soil moisture values were close in both years, the big difference observed in the stomatal conductance was attributed to the difference in temperature, vapor pressure, rainfall amount and wind speed. When the stomatal conductance was below $200 \mathrm{mmol} \mathrm{m}^{-2} \mathrm{~s}^{-1}$, no external intervention for the stress relief helped to increase the conductance.

In both years, during the flowering-boll development and boll opening periods (TOO), all the $S$ doses were sufficient for the stress relief. However, with $S_{3}$ (the highest $\mathrm{S}$ dose), the stress was prolonged. Nevertheless, $\mathrm{S}_{3}$ increased the stomatal conductance with OTT. 


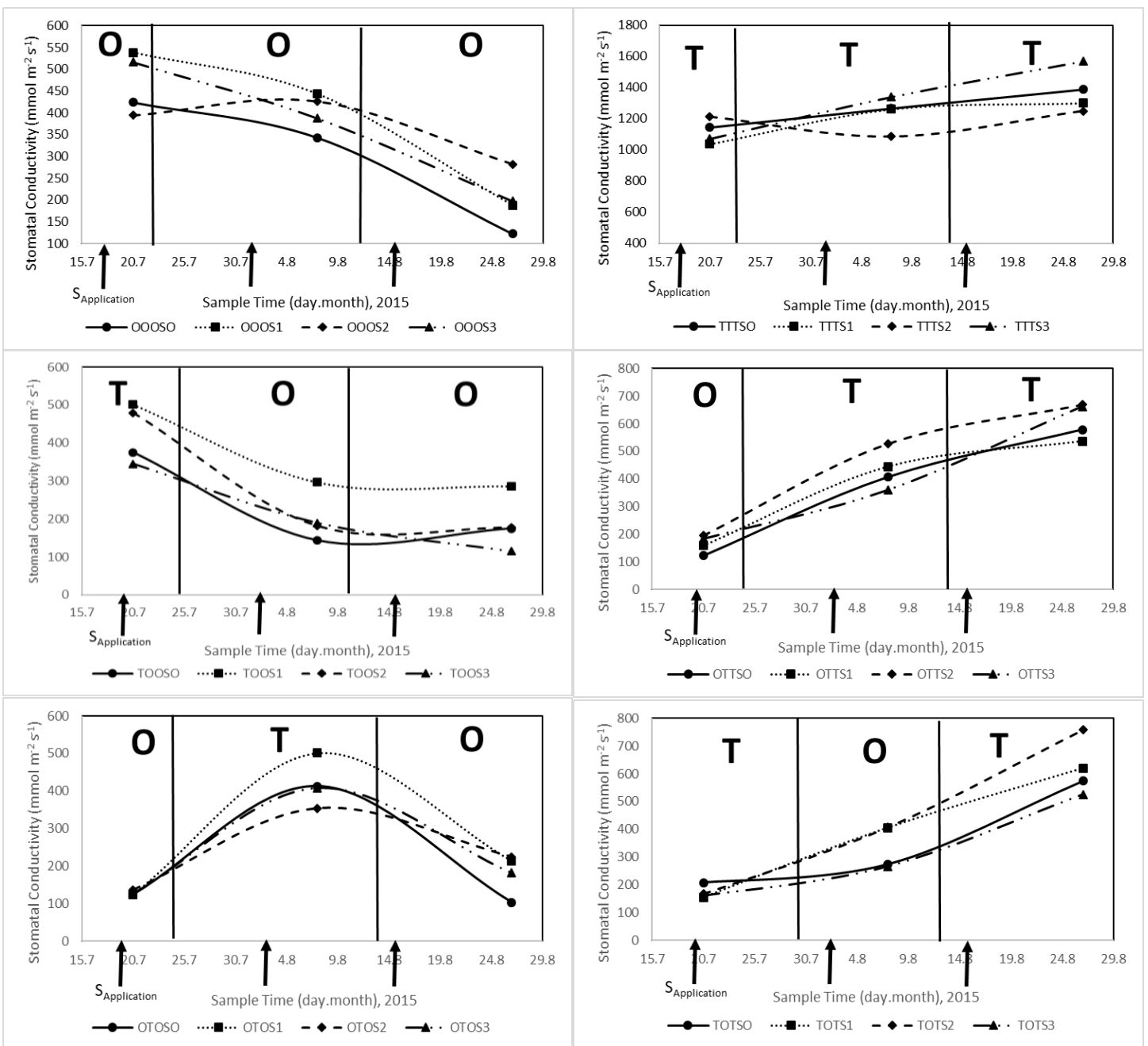

Figure 3. The effect of applied sulfur doses on stomatal conductance, 2015

In the first year, the $S$ doses had no effect on the vegetative growth with ОTO. However, $\mathrm{S}_{3}$ increased the stomatal conductance to enable the plant to survive without stress until the harvest in the second year. In the second year, the lack of irrigation during the flowering and boll formation periods (2nd period) with TOT caused a stress and reduced the stomatal conductance (Figure
4). However, this expected effect was not observed in the first year, and the stomatal conductance rose at the time of stress thanks to $S_{1}$ and $S_{2}$ (Figure 3).

Overall, the foliar $S$ applications $\left(S_{1}: 150 \mathrm{ml} \mathrm{da}^{-1}\right.$; and $S_{2}$ : $250 \mathrm{ml} \mathrm{da}^{-1}$ sufficiently alleviated the stress in the cotton under the prolonged stress, whereas $\mathrm{S}_{3}$ further stressed the plant and decreased its stomatal conductance. 


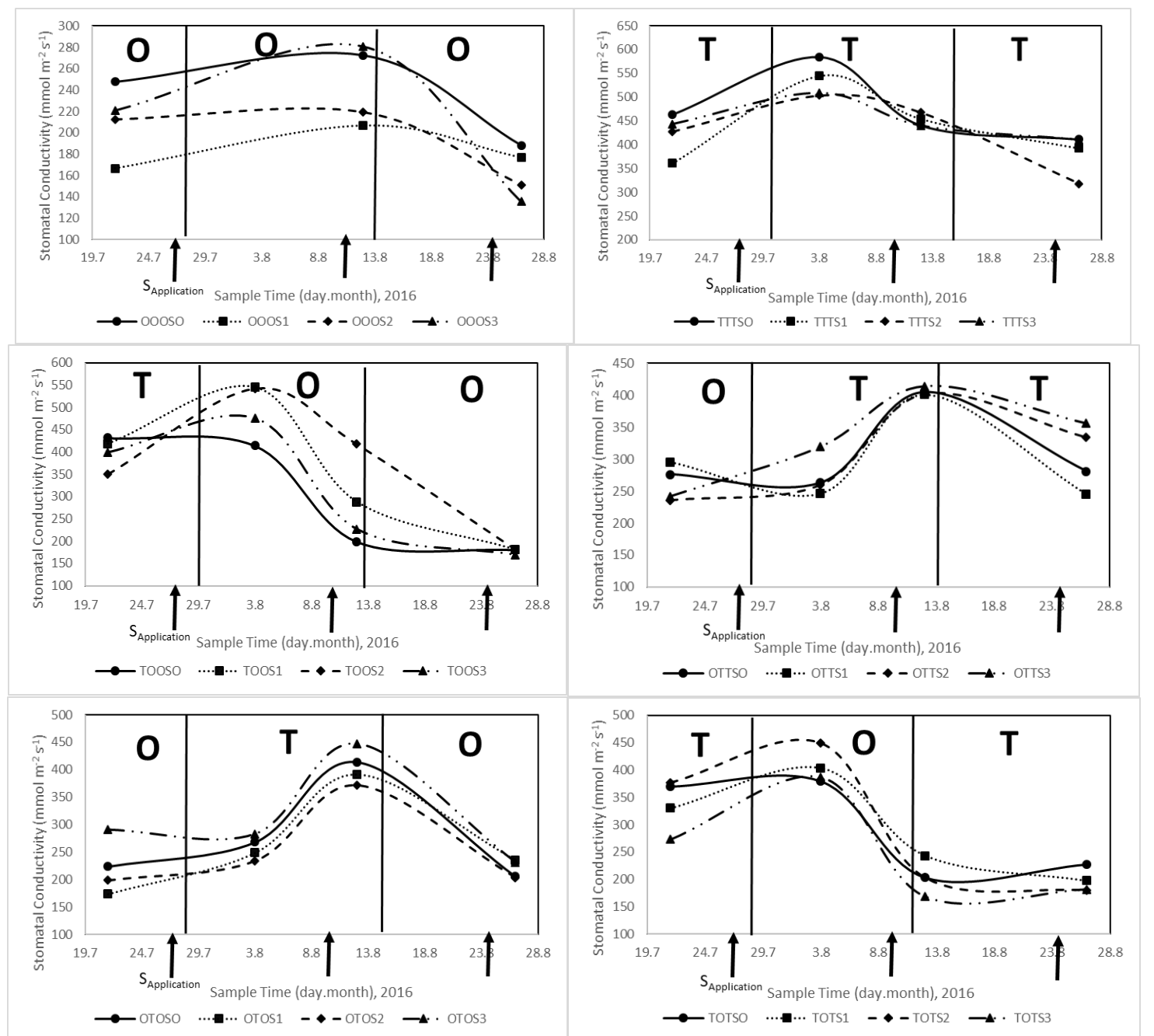

Figure 4. The effect of applied sulfur doses on stomatal conductance, 2016

\section{CONCLUSION}

The water stress sensitivity of the cotton changed according to its developmental stage. How to enhance its resistance to the soil water deficiency (water stress) during the developmental periods was not explored. In this experimental study, an irrigation strategy was designed to quantify the effect of the stress duration and severity on the stomatal conductance as well as of the foliar $S$ application on the increased stomatal conductance for the different developmental stages of the cotton grown in the Mediterranean region. $S_{1}$ and $S_{2}$ doses had a more positive contribution on the stomatal conductance. The plant under the sufficient soil water content (TTT) could not open its stoma any further as a result of the foliar S application. On the contrary, the restrictive $S$ layer on the leaf surface reduced the potential stomatal conductance rate. In conclusion, whatever the expected result may be, the $S$ application with the irrigation at the field capacity level is not considered necessary.

\section{ACKNOWLEDGEMENT}

This study was supported by the Scientific Research Projects Unit of Hatay Mustafa Kemal University (Project No: 14100). It is a part of the "Master of Science Thesis" carried out at the Department of Biyosistem Engineering at the Science Institute of Hatay Mustafa Kemal University.

\section{CONFLICT OF INTEREST}

The authors declare no conflict of interest for this study.

\section{AUTHOR'S CONTRIBUTIONS}

The contribution of the authors is equal.

\section{REFERENCES}

Andersen MN, Jensen CR, Lösch R (1992) The interaction effects of potassium and drought in field-grown barley. 1. yield, water-use efficiency and growth. Acta Agricultural Scand. Sect. B Soil Plant Sciences 42: 34-44

Bek Y, Efe E (1988) Research and Experiment Medoths I. 
Cukurova University, Faculty of Agriculture Adana, Turkey. Textbook: pp.395 (in Turkish).

Blum A (1986) Breeding crop varieties for stress environments. Critical Reviews in Plant Sciences 2: 199-237.

Burt CM, O'connor K, Ruehr T (1995) Fertigation. Irr. Training and Research Center. Cal. Polytec. St. Univ., San Luis Obispo, Ca 93407, Isbn 0-96436341-0. Pp.295.

Can D (2017) Determination of the effects of deficit irrigation on quality, yield and yield components of some cotton variety in Amik Plain conditions. (M.Sc. Thesis). Mustafa Kemal University Institute of Science and Technology, Department of Biosystems Engineering. Hatay (in Turkish).

Dietz KJ (1989) Recovery of Spinach leaves from suphate and phosphate deficiency. J. Plant Physiol. 134: 551-557.

Doorenbos J, Kassam A H (1979) Yield Response to Water, Rome, FAO 33, pp.193.

Fox RL, Olson RA, Rhoades HF (1964) Evaluating the sulfur status of soils by plants and soil tests. Soil Sci. Soc. Am. Proc. 28: 243-246

González A, Martin I, Ayerbe L (2008) Yield and osmotic adjustment capacity of Barley under terminal water- stress conditions. Journal of Agronomy and Crop Science 194: 81-91.

James LG (1988) Principles of Farm Irrigation System Design. Krieger Publishing, New York, pp.543.

Jie X, Dong Q, Zhou L (2008) Effects of sulfur nutrition on the chlorophyll content of maize leaf under zinc and drought stress. Agricultural Research in the Arid Areas-02.

Jones HG (1999) Use of thermography for quantitative studies of spatial and temporal variation of stomatal conductance over leaf surfaces. Plant Cell Environ. 22: 1043-1055.

Kazgoz Candemir D, Odemis B (2018) Effects of foliar sulfur applications in reducing water stress applied to the cotton plant (Gossypium hirsutum L.) during different development periods. Derim 35(2): 161-172. (in Turkish).

Kerepesi I, Galiba G (2000) Osmotic and salt stressinduced alteration in soluble carbohydrate content in wheat seedlings. Crop Sci. 40: 482-487.

Keten M, Degirmenci H, Guvercin RS (2019) Determination of drought tolerance for some cotton genotypes (gossypium hirsutum I.) under deficit irrigation conditions. KSU J. Agric Nat. 22(5): 685-693.(in Turkish).

Krieg DR (1997) Genetic and environmental factors affecting productivity of cotton. In: Proceedings
Beltwide Cotton Production Research Conference, 7-10 January, New Orleans, LA, pp.1347.

Lawlor DW, Cornic G (2002) Photosynthetic carbon assimilation and associated metabolism in relation to water deficits in higher plants. Plant Cell Environ. 25: 275-294.

Loka DA (2012) Effect of water-deficit stress on cotton during reproductive development. Ph.D. Dissertation, University of Arkansas, Fayetteville, Ark.

Loka DA, Oosterhuis D (2012) Water stress and reproductive development in cotton. Department of Crop, Soil and Environmental Sciences University of Arkansas, Fayetteville, AR 72704, Chapter 5.

Loka DA, Oosterhuis D (2014) Water-deficit stress effects on pistil biochemistry and leaf physiology in cotton (gossypium hirsutum, I.) South African Journal of Botany 93, July 131-136.

Mansfield TA, Davies WJ (1981) Stomata and stomatal mechanisms. in: Paleg Lg, Aspinall D (Eds) The Physiology and Biochemistry of Drought Resistance in Plants. Academic Press, New York, 315-346.

Marschner H (1995) Mineral nutrition of higher plants. 2nd Ed., 1-889. Academic Press. New York.

Odemis B, Akıscan Y, Akgol B, Can D (2017) The effect of sulfur doses applied from the leaf under the deficit irrigation conditions on the drought tolerance of the cotton plant. Scientific and Technological Research Council of Turkey (TUBITAK) (Project No: 2140254). (in Turkish).

Odemis B, Delice H (2018) The Effect of different boron levels on the yield and some physiological properties of cotton plant in deficit irrigation water conditions. Proceedings of XIX. World Congress of GIGR (International Comission of Agricultural and Biosystems Engineering), 22-25 April, Antalya, pp: 28-36.

Orgaz F, Mateos L, Fereres E (1992) Season length and cultivar determine optimum evapotranspiration deficit in cotton. Agron. Journal 84: 700-706.

Ozyurt IK, Akca K (2017) Determination of the effects of drought stress on the stomata and other morphological traitsin prunus mahaleb I. rootstocks. Journal of Agricultural Faculty of Gaziosmanpasa University, 34 (Additional number): 34-40. (in Turkish).

Richards RA (2006) Physiological Traits Used in the Breeding of New Cultivars for Water-Scarce Environments. Agric. Water Manage. 80: 197-211. 
Sawwan J, Shibli RA, Swaidat I, Tahat M (2000) Phosphorus Regulates Osmotic Potential and Growth of African Violet under In Vitro-Induced Water Deficit. J. Plant Nutr. 23: 759-771.

Slafer GA, Araus JL, Royo C, Del Moral LFG (2005) Promising Ecophysiological Traits for Genetic Improvement of Cereal Yields in Mediterranean environments. Ann. Appl. Biol. 146: 61-70.

Sezener V, Basal H, Peynircioglu C, Gurbuz T, Kizilkaya K (2015) Screening of cotton cultivars for drought tolerance under field conditions. Turkish Journal Field Crops 20(2): 223-232.

Sinclair TR (2005) Theoretical analysis of soil and plant traits influencing daily plant water flux on drying soils. Agronomy Journal 97: 1148-1152.

Turner NC (1997) Further progress in crop water relations. Advance Agronnomy 58: 293-338.

Walter A, Shurr U (2005) Dynamics of leaf and root growth: Endogenous Control Versus Environmental İmpact. Ann. Bot. 95: 891-90. 